\title{
BUS TICKET BOOKING INFORMATION SYSTEM
}

\author{
Setya Chendra Wibawa ${ }^{a}$, Doni Abdul Fatahb, Moch. Mifahul Huda Firmansyahb, Nur H. \\ Mustafit $^{\text {b }}$, Dini L. A. ${ }^{\text {, }}$ Eka R. Putri ${ }^{\text {, }}$, Cholik Setyo Laksono ${ }^{b}$ \\ ${ }^{a}$ Information Engineering, Universitas Negeri Surabaya, Surabaya, Indonesia \\ ${ }^{b}$ Information System, University of Trunojoyo Madura, Surabaya, Indonesia
}

\begin{abstract}
A B S T R A C T
This article was written during the covid pandemic, during a pandemic like this one's mobility is being limited. So that it has a big impact on activities that are usually carried out, including the case in the field of transportation. In this case, people tend to reduce being outside their homes and also avoid crowds to minimize exposure to the Covid-19 virus. This also affects the sale of vehicle tickets from various aspects ranging from air, land and sea. To overcome this problem, a bus ticket booking website was created. With this bus ticket booking website, tickets can be purchased without having to come directly to the ticket sales outlet. Buyers can buy tickets via smartphones or laptops by accessing this bus ticket booking website. Not only simplifying the ticket buying process, it can also help reduce the crowds that could be generated in the process of buying and selling tickets. So that the existence of a bus ticket booking website is expected to help reduce the number of people exposed to the corona virus as well as simplify and shorten transactions made by buyers.
\end{abstract}

Keywords: Covid, Bus, Ticket, Website.

Article History

Received 12 August 21

Received in revised form 10 September 21

Accepted 20 November 21

\section{Introduction}

The internet is a medium of information that is very easy to be accessed by everyone through various types of existing communication devices, ranging from computers, notebooks and smartphones [1]. This opens up opportunities for companies to develop services, in terms of business, relationships or as a means to introduce the company to the wider community through the internet, one of which is a transportation service provider [2].

During a pandemic like this, one's mobility is being restricted. So that it has a big impact on activities that are usually carried out, including the case in the field of transportation. In this case, people tend to reduce being outside their homes and also avoid crowds to minimize exposure to the Covid-19 virus [3]. This also affects the sale of vehicle tickets from various aspects ranging from air, land and sea [4].

From these problems, we need an information system that is expected to increase ticket sales [5]. In this case, an online-based vehicle ticket sales information system is made. What is meant is that tickets can be purchased without having to come directly to the ticket sales outlet [6]. Not only simplifying the ticket buying process, it can also help reduce the crowds that could be generated in the process of buying and selling tickets [7].

This information system is more intended for booking bus tickets. So that a forum is formed which is expected to be able to overcome these problems.
Namely making an online-based bus ticket sales information system designed to make it easier for someone to order bus tickets [8] [9].

\section{Methods}

\subsection{System Requirements Survey}

The research method used is a case study with the following stages:

1. Field Survey

In this information system, we conduct a survey on pre-existing websites in terms of ordering tickets online, which are related to ticketing, both in terms of observing and deepening existing features that will later be developed. In addition, we also conducted visits and interviews at PT. Damdam to find out the needs, operations, and data needed so that the system we created can be useful and in accordance with what is in the company [10].

2. Literature Study

Browsing the internet to get theories, tutorials and examples of website applications, which will be needed in the website design process [11]. Learn website design techniques using HTML, and web programming using PHP and MySQL. Conducting a literature study on software design in the field of ticket booking [12].

\subsection{System Requirements Analysis}

The type of website that will be created is a dynamic website, this website will allow interaction between users and the facilities provided [13]. To run the website, an application is needed to manage data and display the

* Corresponding author.

E-mail address:doni.fatah@trunojoyo.ac.id. 
processed data in the form of the required information. The following is the information that will be generated by this website:

1. Ticket purchase transaction report, this report contains buyer data, departure location and destination, and departure schedule.

2. Ticket sales report per location, this report contains ticket sales reports based on the departure location. So the manager can monitor any location that is crowded by bus users.

3. Monthly ticket sales report, this report contains a monthly ticket sales report.

4. Annual ticket sales report, this report contains a report on the overall ticket sales each year.

\subsection{Software Requirements Analysis}

The software used to design a website on a server computer is as follows:

1. Operating system: windows 10.

2. XAMPP which contains the Apache web server and MySQL.

3. Visual studio code as HTML and PHP editor.

For the software used to run the website on the client computer, it is enough to use a web browser such as: Google Chrome, Microsoft Edge, etc.

\subsection{Hardware Requirements Analysis}

The hardware needed to design a website on a server computer is as follows:

1. A computer with an intel core $\mathrm{i} 3-5005 \mathrm{u} 2 \mathrm{GHz}$ processor.

2. Hard disk with a capacity of $500 \mathrm{~GB}$.

3. RAM 4GB.

4. VGA Intel HD graphics 5500.

For the hardware needed by the client computer to run the website, it doesn't have to be as good as the server computer, as long as the client computer can run the web browser smoothly, that's enough.

\subsection{Operator Needs Level Analysis}

Operators are expected to be able to operate computers well. Understanding of the task at hand. Each operator can cooperate with each other in the division of tasks and can assist the tasks of other operators if there are obstacles.

\subsection{Actors}

There are 2 actors / roles in the website that we make, including:

1. User / user

People who want to buy tickets for tourist trips by choosing a tour package and means of transportation that will be used

2. Admin

Admin travel PT. Damdam

\subsection{Use Case}

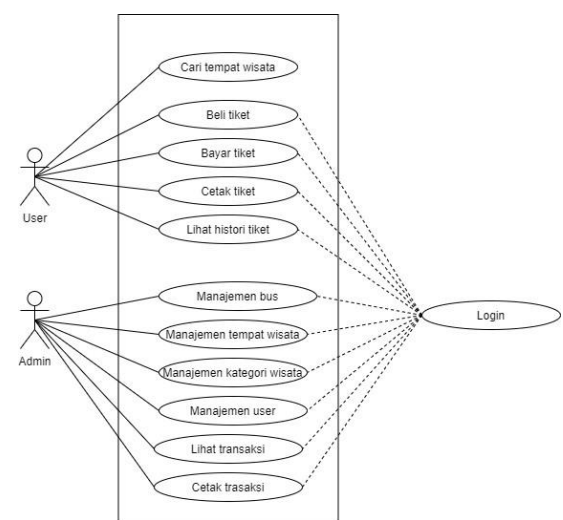

Figure 1. System Use Case

\subsection{Activity Diagram (BPMN)}

The following shows the activity diagram of the ticket website design

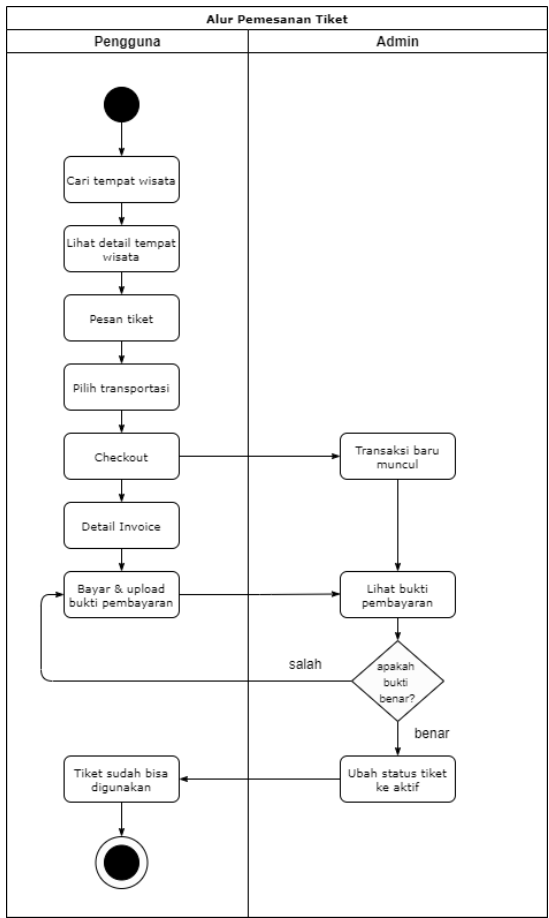

Figure 2. Activity Diagram System

\subsection{Sequence Diagram}

a. Sequence Diagram Admin

The Admin Sequence Diagram is used when the system first starts displaying the main menu. The following is a sequence diagram of the

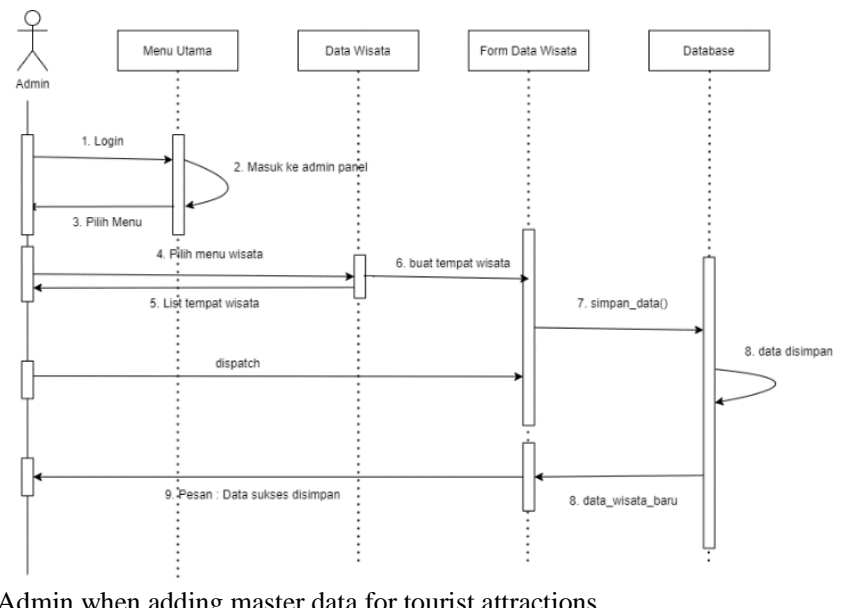

Figure 3. Sequence Diagram Admin

b. User Sequence Diagram 
The following User Sequence Diagram is the flow of users starting from logging in and registering to making transactions by buying a tour ticket and a choice of bus transportation.

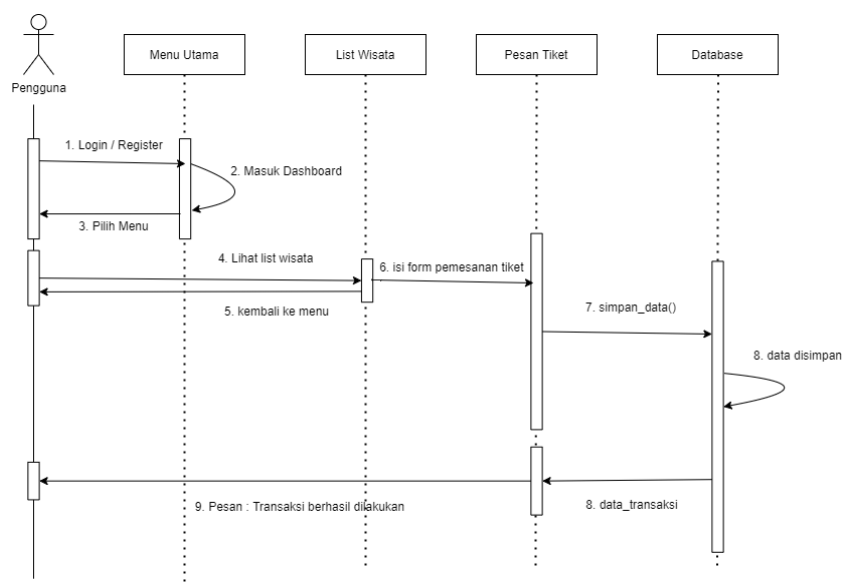

Figure 4. User Sequence Diagram

\subsection{Data Model}

Data Modeling is the process of producing a descriptive diagram of the relationship between various types of information to be stored in the database. The following is a conceptual data model diagram of the bus ticket booking information system:

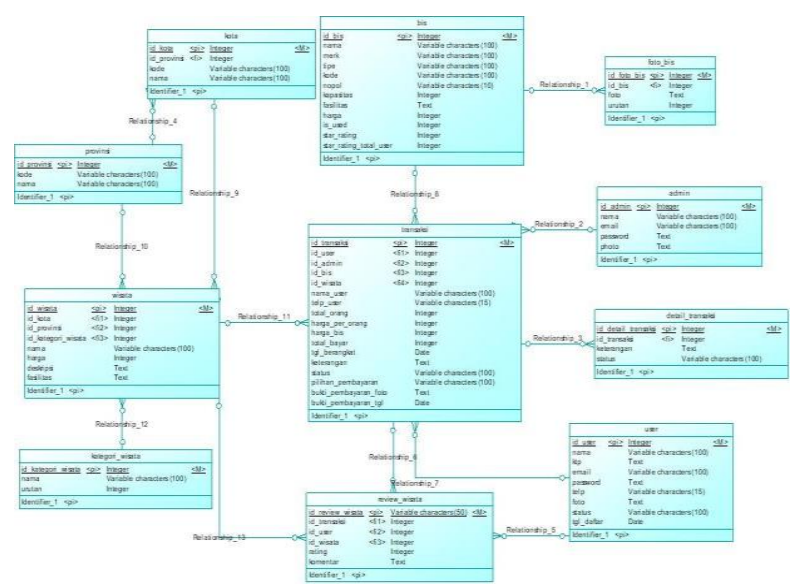

Figure 5. Data Model System

\section{Result}

\subsection{User Page}

a. Home View

In the home view, displays information about the advantages of PT. DamDam itself and also the latest tourist destinations available. Delivered quite simply but can be easily understood by the user. The appearance itself is uniform and also according to the chosen theme. Like the button on this website, the button is marked in green, but after a response from the user, the button changes color to red. And this applies to every button in the menu on this website. As in the following picture.

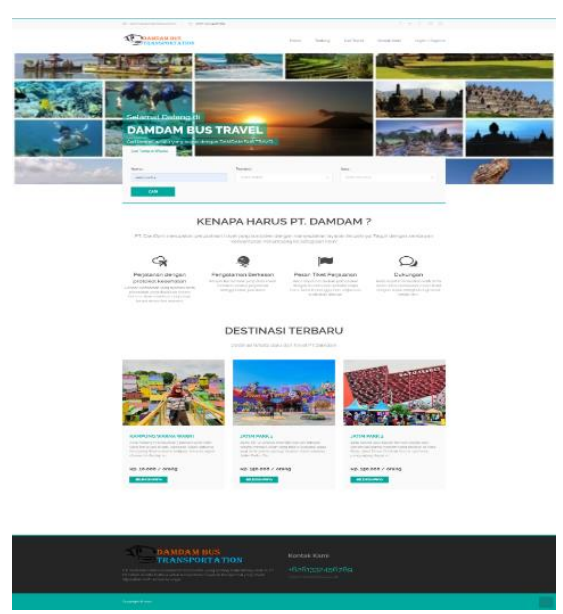

Figure 6. Home View

b. View About

Not much different from the appearance of the home page, on the appearance of the About page it still uses matching colors that match the theme, has a navbar and footer that matches all pages that display a little contact information from PT.DamDam. The page about this also provides information about PT. DamDam itself, ranging from employees, what is offered, and also many others.

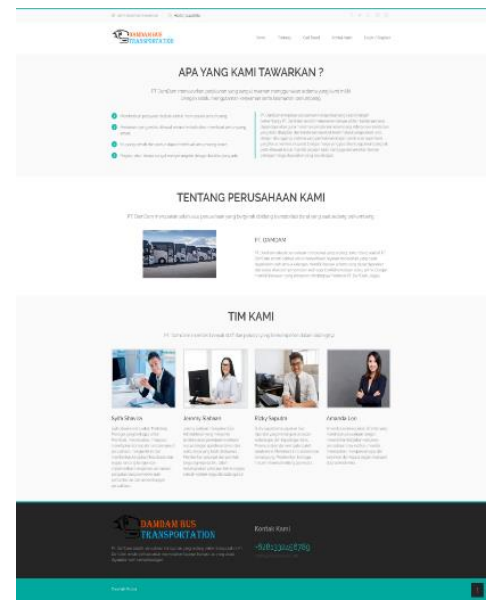

Figure 7. View About

c. View Search Travel 
In the Search Travel page, there is a clear difference when we log in or not. This is the main page of Search Travel.

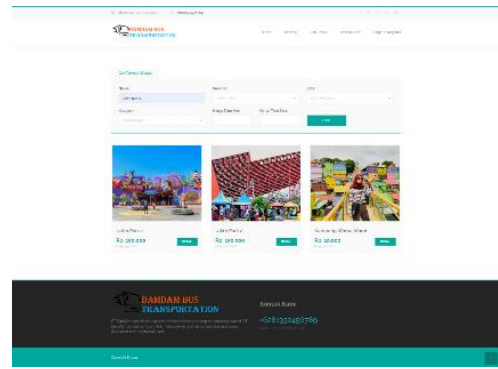

Figure 8. View Search Travel

d. Transaction Checkout Page

The ticket has been successfully created, then the user can select the bus and payment bank and press checkout to create a new invoice

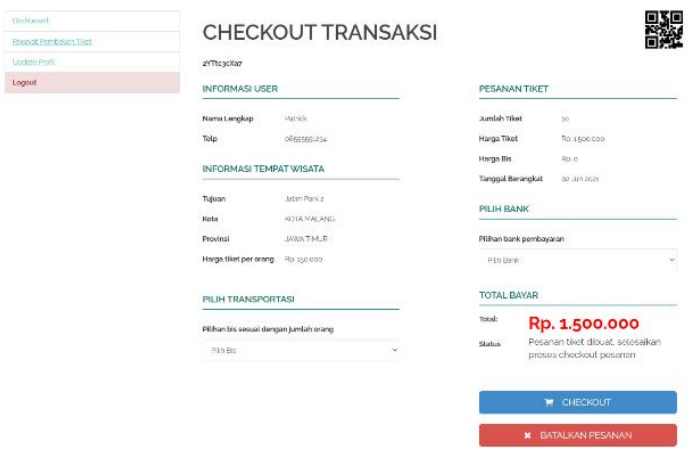

Figure 9. Transaction Checkout Page

\section{Conclusion}

The conclusion from the explanation above is, with the Bus Ticket Booking Information System PT. This DamDam is expected to make it easier for consumers to book travel buses at the same time as booking tickets to the destinations they want to go to. With this information system, it can also make it easier for travel bus business owners to manage their business. Not only makes it easier for consumers and business owners, but this information system also has a positive impact on the destination, because it can simultaneously promote these places.

\section{REFERENCES}

[1] Veronica and I. M. Sari, "The design of web-based information system of community progress," Proc. 2016 Int. Conf. Inf. Manag. Technol. ICIMTech 2016, no. November, pp. 301-306, 2017, doi: 10.1109/ICIMTech.2016.7930349.

[2] E. Oktaviani, U. Cahyana, and A. Purwanto, "Development of Web-
Based Chemical Learning Media in Coloid System Topic Using Wordpress,” JTK (Jurnal Tadris Kim., vol. 5, no. 1, pp. 104-117, 2020, doi: 10.15575/jtk.v5i1.7425.

[3] G. A. M. Suartika, S. M. Said, and K. E. Saputra, "Numerical-Based Computerized Modelling for Tsunami: Initiating Planning for Natural Disaster of South Kota Denpasar-Bali,” Int. J. Adv. Sci. Eng. Inf. Technol., vol. 11, no. 2, pp. 474-481, 2021, doi: 10.18517/ijaseit.11.2.12600.

[4] D. S. Hui et al., "The continuing 2019-nCoV epidemic threat of novel coronaviruses to global health - The latest 2019 novel coronavirus outbreak in Wuhan, China," Int. J. Infect. Dis., vol. 91, pp. 264-266, 2020, doi: 10.1016/j.ijid.2020.01.009.

[5] Y. Guan, B. Wu, and J. Jia, "Does online ticket booking system make people better off? An empirical study on railway service," Transp. Res. Part F Traffic Psychol. Behav., vol. 73, pp. 143-154, 2020, doi: 10.1016/j.trf.2020.03.014.

[6] P. Sarkar and M. S. Noel, "a Project on Online Ticket Booking System,” Int. Res. J. Eng. Technol., no. May, pp. 1705-1711, 2020, [Online]. Available: www.irjet.net.

[7] A. A. Dar and N. Anuradha, "Application of Call Option in an Airline Ticket Booking Process,” vol. 29, no. 5, pp. 9471-9479, 2020.

[8] K. Ahmed, A. Khan, O. A. Siddiqui, S. A. Iftikhar, B. Das, and M. Khurrum, "Proposed Efficient Method for Ticket Booking (Pemtb)," J Fundam Appl Sci, vol. 10, no. 6S, p. 322, 2018.

[9] A. F. Doni, F. A. Mufarroha, Y. D. P. Negera, and E. Sugiarti, "Development of Web Based Information System for Branding Services," IOP Conf. Ser. Mater. Sci. Eng., vol. 1125, no. 1, p. 012051, 2021, doi: 10.1088/1757-899x/1125/1/012051.

[10] M. Younas, D. N. A. Jawawi, I. Ghani, and R. Kazmi, "NonFunctional Requirements Elicitation Guideline for Agile Methods," J. Telecommun. Electron. Comput. Eng., vol. 9, no. 3-4 Special Issue, pp. 137-142, 2017.

[11] D. Arora, K. F. Li, and S. W. Neville, "Consumers' sentiment analysis of popular phone brands and operating system preference using twitter data: A feasibility study," Proc. - Int. Conf. Adv. Inf. Netw. Appl. AINA, vol. 2015-April, pp. 680-686, 2015, doi: 10.1109/AINA.2015.253.

[12] M. Renee Garett, MS, LCSW, Jason Chiu, MS, Ly Zhang, Sean D. Young, $\mathrm{PhD}$, "A Literature Review: Website Design and User Engagement Renee,” Online J Commun Media Technol, vol. 46, no. 5, pp. 1247-1262, 2017, doi: 10.1002/jmri.25711.PET/MRI.

[13] R. Alanezi, M. A. Alanezi, and N. A. Khan, "Development of Web Based E-Cooperative Training System," 2018 Int. Conf. Smart Comput. Electron. Enterp. ICSCEE 2018, pp. 1-6, 2018, doi: 10.1109/ICSCEE.2018.8538367. 